\title{
Gerard Siwek CSsR, Rekolekcje wczoraj i dziś Wydawnictwo Homo Dei, Kraków 2011, ss. 238
}

Posługa duszpasterska Kościoła w Polsce realizuje się na wielu płaszczyznach zaangażowań. Przez ponadtysiącletnią historię odkrywanie powinności pasterskich prowadziło ku budowaniu wspólnoty wierzących, których jednoczyła jedna wiara i jedna historia ziemi, na której żyją. Na przestrzeni wieków głoszenie słowa Bożego i sakramentalna posługa łączyła się z troską o kształtowanie społeczności wierzących, którzy są odpowiedzialni za swoją wolność nie tylko w wymiarze religijnym, ale również społecznym. Termin Antemurale christianitatis, przypisywany Rzeczpospolitej przez innych uświadamia głębokie przywiązanie do wiary i Tradycji, z których wypływa troska o zapewnienie i rozwijanie własnej tożsamości, a w chwilach doświadczeń także gotowość oddawania życia. Budowanie wspólnoty Kościoła zakłada jednocześnie utrwalanie więzów społecznych, które ułatwiają i wspomagają realizowanie chrześcijańskich zobowiązań w życiu codziennym. Konkret życia prawdziwie chrześcijańskiego nie wyczerpuje się w wymiarze kultycznym, ale jest realizacją wezwania misyjnego Jezusa Chrystusa, które zobowiązuje nie tylko uczestników kapłaństwa służebnego, lecz również kapłaństwa królewskiego, czyli wszystkich ochrzczonych.

Polska rzeczywistość duszpasterska niejednokrotnie określana jest jako duszpasterstwo masowe. Wielu obserwatorów życia religijnego, często z tym religijnym życiem niezwiązanych, w sposób pejoratywny ujmują formy podejmowanych inicjatyw duszpasterskich. Wielu pamięta jeszcze wielki wysiłek duszpasterski Prymasa Tysiąclecia Kardynała Stefana Wyszyńskiego wokół dzieła koronacji wizerunków Matki Bożej. Do dzisiaj pozostają i owocują wydarzenia, które przed laty gromadziły po kilkadziesiąt, czy kilkaset tysięcy wiernych. Zapoznając się z historią tamtych lat warto zwrócić uwagę, jak wiele czyniła władza totalitarna, by nie dopuścić do licznych zgromadzeń ludzi, których łączy duch wiary. Nie można także zapominać, o osobach, dla których tak liczne zgromadzenia wiernych były synonimem płytkiej pobożności i rozwiniętej emocjonalności, bez duchowego pogłębienia.

Pośród różnych form duszpasterskiego zaangażowania miejsce szczególne zajmują rekolekcje. Chrześcijanie na wzór Jezusa Chrystusa, który przed rozpoczęciem swojej publicznej działalności wyszedł na pustynię; mają podejmować osobiście trud wychodzenia na pustynię swego serca, aby poznawać Boga, siebie i bliźnich. Jest to okazja bardziej świadomego i pełniejszego odkrywania swoich powinności chrześcijańskich i rozwoju, który nie kończy się wraz z zamknięciem czasu katechizacji.

Ksiądz Gerard Siwek CSsR podjął się trudu analizy współczesnych uwarunkowań głoszonego słowa Bożego w ramach posługi rekolekcyjnej. Jego praca 
Rekolekcje wczoraj i dziś jest kolejną z wielu publikacji, które znalazły się w serii „Redemptoris Missio" Jest to trzydziesta pozycja we wspomnianej serii, a siódma autorstwa ks. Siwka. Autor jest cenionym teoretykiem i praktykiem jako wykładowca homiletyki, autor licznych publikacji, a także misjonarz ludowy i rekolekcjonista. Długoletnie doświadczenie oraz praca naukowa i posługa kaznodziejska zaowocowały tym razem publikacją, która wydaje się szczególnie oczekiwaną w coraz lepszym odczytywaniu współczesnych możliwości przepowiadania.

W epoce kiedy słowa tracą swoje znaczenie, albo nabywają nowych niejednokrotnie mylnych opisów, warto spojrzeć na adekwatność słów odnoszonych do konkretnej rzeczywistości. Ksiądz Wiesław Przyczyna w swojej recenzji pracy ks. Siwka stwierdza: „Rekolekcje są jedną z powszechnie znanych form duszpasterskiej działalności Kościoła. Jednak w ostatnim czasie rekolekcjami nazywa się szeroki zakres zjawisk: od wycieczki rowerowej z księdzem po wielodniowe skupienie. Ponadto słowo „rekolekcje” coraz częściej jest łączone z wydarzeniami o zgoła nierekolekcyjnej wymowie. Mamy więc obok rekolekcji ignacjańskich, oazowych - także rekolekcje „tischnerowskie”, „filmowe”, „teatralne”, „muzyczne”, „wędrowne”, „beskidzkie”, „kajakowe”, „karnawałowe” (ostatnia strona okładki). Do tej mnogości i nadużywania terminu rekolekcje nawiązuje autor w Słowie wstępnym (s. 5-7), nie jest to jednak żadna forma narzekania, lecz podejmowanie próby pogłębienia i zrozumienia znaczenia duchowych ćwiczeń. Zapowiada, że jego rozważania mają za cel ukazanie rekolekcji w aspekcie pojęciowym, historycznym, teologicznym i metodycznych.

Praca ks. Gerarda Siwka została podzielona na pięć rozdziałów, z których każdy zawiera po kilka podrozdziałów. Niestety Spis treści (s. 234-236) został umieszczony na końcu publikacji co odrobinę utrudnia bardziej swobodne korzystanie i dobór poszukiwanych zagadnień. Nie umniejsza to jednak w niczym wartości pracy, która zgodnie z tytułem jest próbą spoglądania w przeszłość i na dzisiejsze możliwości korzystania z rekolekcji. Pierwszy rozdział: Pojęcie rekolekcji (s. 9-34) przybliża miejsce rekolekcji w homiletyce i wyjaśnia terminy, które oddają specyfikę poszczególnych form duchowego zaangażowania. Kolejny rozdział: Rekolekcje w rozwoju historycznym (s. 35-92) przybliżają dzieje rekolekcji na chrześcijańskim zachodzie i w Polsce. Choć rekolekcje na Zachodzie i w Polsce wchodzą w dynamikę życia Kościoła jednocześnie, autor podejmuje trud wydobycia specyfiki form i lokalnego zabarwienia tych duszpasterskich działań. Ksiądz Siwek dochodzi do smutnej konstatacji dotyczącej misji ludowych i osłabienia ich znaczenia; co nie przeszkadza patrzeć w przyszłość z nadzieją i otwartością w znajdowaniu bogactwa rekolekcyjnych działań. Odrobinę niedosytu budzi brak zainteresowania się formami rekolekcyjnymi na Wschodzie, jeśli takowe są i się rozwijają.

W rozdziale: Teologia rekolekcji (s. 93-130) ks. Siwek dotyka miejsca rekolekcji w dziele i posłannictwie Kościoła, co prowadzi do weryfikacji ich znaczenia w duchowym, indywidualnym rozwoju człowieka. W tym rozdziale podjęto 
także niezwykle istotny aspekt rozeznawania duchowego, który od czasów św. Ignacego z Loyoli wiedzie ku pełniejszemu i odpowiedzialnemu wyborowi drogi życiowej i zaangażowania w życie Kościoła. Kościół jest wspólnotą i budowanie wewnętrznej komunii jest warunkiem skutecznej realizacji posłannictwa misyjnego. Kolejny rozdział to: Rodzaje rekolekcji (s. 131-158). Autor ukazuje tutaj szeroką panoramę możliwości podejmowania rozwoju duchowego przez znajdowanie właściwej dla siebie formy udziału. Oprócz znanych od dawna form rekolekcji otwartych, czy zamkniętych ks. Siwek dotyka znaczenia i wartości rekolekcji radiowych i internetowych. Współczesne możliwości cywilizacyjne i rozwój elektronicznych nośników informacji są wielką szansą ewangelizacyjną, co jednak wymaga krytycznego spojrzenia i oceny. $Z$ tej racji autor ukazuje m.in. zalety i pułapki rekolekcji internetowych.

Ostatni rozdział pracy to: Rekolekcje w praktyce (s. 159-200). Autor ma szczególne predyspozycje, by zająć się stroną realizacji dzieła rekolekcyjnego w konkrecie duszpasterskiej posługi. Sam bowiem przez długie lata tę posługę realizuje. Jego postulaty odnośnie osoby głoszącego, kwestii liturgii i kierownictwa duchowego oraz realnego spojrzenia na warunki zewnętrzne nie niosą z sobą pozorów teoretyzowania. Wreszcie u kresu rozważań ks. Gerard Siwek zgodnie z ewangeliczną zasadą wydobywania ze skarbca rzeczy starych i nowych Zamiast zakończenia (s. 201-216) prezentuje testy św. Alfonsa Marii Liguoriego dotyczące korzyści z rekolekcji odprawianych w samotności. Wybór jest zrozumiały, bowiem autor korzysta $\mathrm{z}$ bogactwa Założyciela swego Zakonu. Co więcej dzieło prowadzenia i towarzyszenia w rekolekcjach wymaga duchowego zaplecza i osobistego spotkania ze słowem Bożym. Pracę ks. Siwka zamyka Wykaz skrótów (s. 217-220) i Bibliografia (s. 221-233).

Ksiądz Gerard Siwek podjął się przygotowania i opublikowania książki dotyczącej tematyki niezmiernie bliskiej konkretowi duszpasterskiemu. Bogactwo, które płynie z możliwości ewangelizacyjnych w kontekście głoszenia rekolekcji jest niewątpliwe. Jednak odpowiedzialność i rozsądek każe nieustannie weryfikować stan i możliwości jeszcze lepszego duszpasterskiego wydobycia form, które pomogą budować trwałe i silne postawy chrześcijańskie. Solidne podłoże teoretyczne, znajomość historii wiedzie do pokornego wykorzystywania dorobku poprzednich pokoleń w kontekście odkrywania bogactwa słowa Bożego i niesienia go sobie i innym. Praca ks. Siwka, podobnie jak wiele poprzednich może być pomocą tak dla przygotowujących się do w posługi Słowa, jak również to Słowo głoszących. Wydaje się, że będzie szczególnie przydatna dla rekolekcjonistów, którzy zawsze stoją wobec niebezpieczeństwa spowszednienia Słowa i rutyny. Praktyka połączona z refleksją w świetle Bożej prawdy, to także owoc rekolekcyjnego wysiłku.

Ks. Jerzy Swędrowski 